European journal of American studies

\title{
Volunteers of America:
}

From Cotton Mather and Ben Franklin to the "Coalition of the Willing"

\section{Sämi Ludwig}

\section{(2) OpenEdition}

\section{Journals}

Édition électronique

URL : https://journals.openedition.org/ejas/1182

DOI : 10.4000/ejas. 1182

ISSN : 1991-9336

Éditeur

European Association for American Studies

Référence électronique

Sämi Ludwig, «Volunteers of America: », European journal of American studies [En ligne], 2-1 | 2007

document 5, mis en ligne le 16 mai 2007, consulté le 08 juillet 2021. URL : http://

journals.openedition.org/ejas/1182 ; DOI : https://doi.org/10.4000/ejas.1182

Ce document a été généré automatiquement le 8 juillet 2021.

Creative Commons License 


\title{
Volunteers of America:
}

\author{
From Cotton Mather and Ben Franklin to the "Coalition of the Willing"
}

\section{Sämi Ludwig}

Nothing strikes the European traveler in the United States more than the absence of what we would call government or administration.

(Alexis de Tocqueville)

Know all men by these presents, that I, Henry Thoreau, do not wish to be regarded as a member of any incorporated society which I have not joined.

(From: "Resistance to Civil Government") Aux Etats-Unis, le volontariat est indissociable de

la démocratie. (Marc Chénetier) ${ }^{2}$

Look what's happening out in the streets Got a revolution, got to revolution Hey I'm dancing down the streets Got a revolution, got to revolution Ain't it amazing the people I mee Got a revolution, got to revolution

One generation got old One generation got sou

This generation got no destination to hold

Pick up the cry

Hey now it's time for you and me

We are volunteers of America ...

(Jefferson Airplane) ${ }^{3}$

Isn't volunteerism the backbone of American

society?

(Ted Flickinger) ${ }^{4}$ 
It's a free country!

$(\text { proverbial) })^{5}$

1 American volunteerism is a mode of social identity which manifests itself in gestures of explicitly chosen commitment to many different religious, secular, private and public causes, ranging from social affiliation to the institutionalization of societal formations and general trends of privatization in a nation that values "civil society" and nongovernment organizations more highly than any other. Different varieties of "volunteerism" cut across all strands of U.S. society and influence the fabric of American society at every level. Hence much of what Eric Foner writes about "freedom" also applies to "volunteerism," when he writes: "The idea does seem to occupy a more prominent place in our conceptual universe than in other countries" and insists that this "master narrative" "offers a unique vantage point from which to probe the depth of American culture" in the "multifaceted debates over its meaning." 6 If a discussion of "freedom" in many ways contributes to a theory of American identity, a similar discussion of "volunteering" may contribute to understanding its practice, or at least provide a new angle to learn more about it. Still, my very general definition of volunteerism as "voluntary commitment" must be seen as preliminary and tentative. If it cannot serve as a causal explanation of all of these phenomena, at least it can provide us with a heuristically useful angle of analysis and new observations that can in turn provide us with a better understanding of "volunteering." The explanation is not in the word, but, as the American pragmatist philosopher William James would say, it is in the "stream of life" it points to. ${ }^{7}$

2 My own first exposure to American-style volunteerism was as a volunteer for the student exchange organization AFS Intercultural Programs (formerly American Field Service), an organization based on the ideal of intercultural learning as a means to prevent wars, with roots in an ambulance drivers' program that impressed such literary giants as Ernest Hemingway and William Faulkner. ${ }^{8}$ At that time I saw in volunteerism a positive alternative of progressive ideas preferable to what I considered a conservative and narrow-minded Swiss government politics, represented by the police-during the time of the Zürich youth riots in the 1980s young rebels chanted: "Machet us em Staat/Gurkesalat" ("Turn the state into/cucumber salad"). Nongovernment organizations generally were seen as more progressive than the state: AFS, Amnesty International, Third World Foundations, Erklärung von Bern, Médecins Sans Frontières, Max Havelaar, etc. They stood for moral commitment beyond government regulations, traditionalist religion, or commodified fashions.

3 More recently, however, my early enthusiasm for such volunteer identification has somewhat cooled off in view of the dogmatic neo-liberal criticism of government responsibility and the many cutbacks in what is called service public in my own country, i.e., in basic services that the government is supposed to provide for its citizens in order to foster equality among them as a matter of entitlement. The volunteerism of non-government organizations is often expected to replace government involvement as an alternative mode of organization and provide services instead of the government. This attitude is strongly associated with the politicians Margaret Thatcher and Ronald Reagan and an Anglo-American mode of governance, although it has found powerful local supporters in many other countries all over the world. ${ }^{9}$ This alone is reason enough to reconsider the nature of "volunteering" as an American cultural phenomenon. 
4 Moreover, like the claim to "freedom," the gesture of volunteering goes beyond political factions: it can be both progressive and reactionary. ${ }^{10}$ While Jefferson Airplane's "Volunteers of America" protest against the Vietnam War, ${ }^{11}$ many other volunteer groups have, throughout American history, also supported U.S. projects of internal as well as external exploitation and imperialism-think of the National Rifle Association, of vigilante organizations such as the Ku Klux Klan, the Rough Riders, or of all the "think tanks" financed by conservative money that manipulate American public opinion. What is crucial is that in a typical American debate both sides tend to rely on volunteer structures to advance their own cause, a common trait that unifies the great internal diversity of a gigantic country of 300 million inhabitants and is perceived even more so when seen from the outside towards which the United States tends to behave as a more homogenous unit.

5 The non-government element of volunteering may also explain the easy transferability of many American ideas to other nations, and why we find them in many international dissent movements associated with social progress. A new aspect of this transferability is, however, the recent "evangelical" foreign politics of the United States, which moves beyond the orthodox system of "allies" by expecting other nations to voluntarily commit themselves to American strategies in a "coalition of the willing." In this way a specific set of domestically-evolved American values are being projected internationally-and meeting with resistance. Hence also the nature of American volunteerism/voluntarism ${ }^{12}$ and its relationship to political and governmental organizational structures needs more investigation, especially at this point of a somewhat strained transatlantic relationship. Because this issue is a highly complicated one, I see this paper only as the beginning of an archeology that triangulates some of the main issues involved and formulates some tentative opinions, inviting more debate. 13

6 As already stated, volunteerism in America is intimately tangled up with basic notions of "freedom" and "liberty," "mediating institutions," the "consent of the governed," "nongovernmental institutions," or the civic humanist tradition. No authority is meant to curtail an American's chosen commitments. But whereas these particular issues have been analyzed in specialized monographs such as, among others, Stephen Skowronek's Building a New American State, ${ }^{14}$ Michael Schudson's The Good Citizen: A History of American Civic Life, ${ }^{15}$ Gary Wills's A Necessary Evil: A History of American Distrust of Government ${ }^{16}$ or Eric Foner's The Story of American Freedom, ${ }^{17}$ similar academic studies on American volunteerism are lacking, despite the constant tangential references we find in these books. In particular, contrasting points of view from outside the United States are lacking in this scholarly discourse. If this article can make a contribution, it will be that it initiates a preliminary, critical mapping-out of the issue from the outside. This may make the United States look more homogeneous than it does from the "inside," but it may be valuable due to its different sets of assumptions and "blind spots."

7 To learn more about the nature and tradition of American volunteering, this article begins by offering a survey of the theme, followed by an enquiry into the possible historical origins of American volunteerism in the religious commitments of Cotton Mather and in the civic commitments of his secular successor Benjamin Franklin. This will take me, via the issue of military volunteerism, to some observations on the use of volunteerism by the American government, and a discussion of the role of NGO's in the exporting of American democracy abroad. On this last issue I present some arguments 
from Das Ende der Solidarität. Europa und die USA im Umgang mit Staat, Nation und Religion, ${ }^{18}$ a book written by the former Swiss MP Gret Haller that was based on her experience as an OSCE ombudsfrau for human rights in Bosnia.

1.American Volunteerism

America, STAND UP for your rights, and never, never, never be disillusioned into believing that

we have not the right to assist our neighbor, regardless of our job, training or organizational

affiliation.

(Larry M. Curl)

8 My recent Amazon search for books on "volunteerism" yielded 172 hits. A search for "volunteers" even yielded 5,256 hits. Book titles include Volunteers: How to Get Them, How to Keep Them; the almost identical To Lead Is to Serve: How to Attract Volunteers \& to Keep Them; The Volunteer Management Handbook; or simply, Volunteers Wanted. While some books treat volunteerism as an organizational phenomenon and give good management advice, ${ }^{19}$ others have a more ideological bent and intend to recruit volunteers for specific causes. Thus Bill Hybel's The Volunteer Revolution: Unleashing the Power of Everybody is based on the idea that "the church needs more people to be equipped to serve others" and comes up with the "equation X (paid staff) $+\mathrm{Y}$ (volunteers) $=\mathrm{Z}$ (bearing fruit for God's Glory)."20

9 As I already mentioned, there are few books that treat in depth the culture and history of American volunteerism. A possible exception is Susan J. Ellis and Katherine Noyes's By the People: A History of Americans as Volunteers (revised edition 1990), which is, however, the work of professional volunteer organizers rather than of scholars; Ellis even runs her own volunteer web site, called ENERGIZE. Significantly, in their survey of volunteerism, Ellis and Noyes follow the standard periodization of American history, thus implying that there is an original connection between American history and volunteerism. Volunteerism started in colonial America; it contributed to building the new nation, and it equipped the United States with the necessary energy and commitment at every significant turn and development in its later history. At the end of the book we find two very long indexes of individuals and organizations, which are intended to make it possible to find information on almost any volunteer activity in the United States. Nevertheless, this laudable effort at comprehensiveness cannot adequately cope with the phenomenon, since there are simply too many organizations and associations to list. ${ }^{21}$

10 According to Ellis and Noyes, it is significant that in most periods of American history volunteers have acted on both sides of a conflict. Volunteerism is so important because it encompasses all American views, pro and con. Thus while some volunteers have supported abolitionism and the Underground Railroad, others organized the Ku Klux Klan and similar vigilante movements. ${ }^{22}$ On vigilante movements, Ellis and Noyes generally observe: "Vigilantes considered themselves publicly spirited." Between 1767 and 1910 they find "at least 327 separate movements ... of these voluntary justice seekers." ${ }^{23}$ Curiously, the vocabulary of vigilance was also used by abolitionists, for example, by Thoreau in his "Plea for Captain John Brown" (1860). ${ }^{24}$

11 A typical aspect of social organization in the United States is the limitation of government involvement. Many concerns of public life for which the government is responsible in other countries (and for which it often even has the exclusive 
privilege $)^{25}$ are privately organized. Americans tend not to want to rely (or depend) on government structures, and the boundary between volunteer organization and forprofit corporate business is often blurred. Thus the development of the Western frontier, for example, was delegated to venture capitalism. Private railroads controlled the development of towns and, as Alan Trachtenberg illustrates so impressively, even set up the system of American standard time zones. ${ }^{26}$ At the same time responses to the social ills of the industrial revolution largely remained a preoccupation of various philanthropic charities inspired by the social gospel. Only with the slow development of Progressivism and the economic crisis of 1929 did the New Deal materialize as a period of big government-sponsored programs, ${ }^{27}$ which were, however, powerfully interlaced with volunteer support.

12 Contemporary America thus takes volunteerism for granted. If we Google the term "volunteer," we find an unending number of web sites praising this American quality, providing advice, and offering many opportunities for volunteering. American identity is formed by volunteerism and claims it as an American virtue. Thus Cynthia Schneider, a former US ambassador to the Netherlands, observes that Georgetown University includes "public service as a requirement for graduation," and continues that "public service is a critical component of American institutions that have spread worldwide such as the Girl and Boy Scouts or the Salvation Army." 28 At times the American advocacy of volunteerism may even sound shrill (if not tautological), as in Larry M. Curl's assertion of "the Right of All Citizens to volunteer freely." The chairman of the vCOS (Volunteer and Combination Officers Section of the International Association of Fire Chiefs) ends his web statement as follows: “America, STAND UP for your rights, and never, never, never be disillusioned into believing that we have not the right to assist our neighbor, regardless of our job, training or organizational affiliation." 29 The militancy of this language makes one wonder whom it intends to oppose. Who might deny our right to help? The reader senses a quasi-religious urgency in this commitment that seems to hearken back to historical calls for revolutionary independence. ${ }^{30}$

13 Volunteerism is part of an American tradition of "public service" as a bottom-up attitude of private commitment to public causes; it is precisely not organized top-down by the state and its constitutional governmental structures. In this sense, it is even directly the opposite of our European notion of service public, i.e., services that the state is legally bound to provide for its own citizens, such as basic health insurance, taking care of the poor, providing good public education, child care facilities, public transportation, linear pricing of postal services and telephone, and non-commercial broadcasting. ${ }^{31}$ To examine further the various notions of "service" operating in American culture, the writings of Cotton Mather and Benjamin Franklin as two important originators of American volunteerism will now be analyzed, with special attention for the metaphors and concepts they used to express them.

2. Religious Volunteerism

That a Fit Number in a Neighbourhood, whose Hearts God has touched with a Zeal to Do Good, would Combine into a Society....

(Cotton Mather)

14 One crucial source of American volunteerism is religion, and in particular the American kind of Puritan Protestantism. Though its values are neither representative of the gender situation nor of ethnic minorities in the United States, they have had a 
powerful cultural influence and are considered original to Anglo-American politics, economics, and learning. Puritan separatists believed in the free choice of worship (what Luther would call "the liberty of a Christian"32), non-conformity, and the notion of an individual calling (what Foner calls an "equation of liberty with moral action." 33 Americans actively chose their own religious denomination rather than inheriting it, as most citizens of European nations do. Thus the Swiss Amish and Mennonites, for example, decided to emigrate to the New World because they were persecuted by the dominant Protestant church at home. For these immigrants religious freedom was closely associated with political freedom, an effort by the country populace to throw off the yoke of their city masters. Hence many Anabaptist movements stemmed from earlier rural revolts and wars. Moreover, this close association of religion and voluntary commitment creates a chiasmic relationship in which voluntary religion brings about religious volunteerism.

15 Hence it is no coincidence that the earliest vision of an "American" volunteer organization can be found in Cotton Mather's Bonifacius (1710). ${ }^{34}$ This book, which is subtitled An Essay Upon the Good that Is to Be Devised and Designed, presents Mather as the original "do-gooder," outlining the first formal design for a volunteer organization in America. ${ }^{35}$ In Bonifacius, we find two closely connected tendencies, one concerned with ideology, the issue of missionary work, evangelization, and giving away Bibles, and one concerned with charity and good works in a more practical sense. Yet for Mather it is clear that doing good correlates with Grace:

It is an Invaluable Honour, To Do Good; It is an Incomparable Pleasure. A Man must Look upon himself as Dignifyed and Gratifyed by GOD, when an Opportunity to Do Good is put into his Hands. He must Embrace it with Rapture, as enabling him directly to answer the Great END of his Being.(M23)

16 Before you can do good, you have to be saved (elected) by God. Thus Mather writes in paragraph 7: "Sir, All your Attempts at Good Works will come to Nothing, till a Justifying Faith in your Saviour, shall carry you forth unto them."(M35) And later he explains: "Sirs, It is, that you may Do Good on a Divine Principle; Good, merely for the Sake of Good! Lord, Increase our Faith!"(M79) Mather's "goodness" is defined in a binary metaphysics of good vs. evil: "Why should not we be as Wise to Do Good, as any People are Wise to do Evil?"(M30) It is solidly rooted in Manichean conceptualism.

17 Because doing good is the fruit of God's Grace, one should not expect worldly gratitude. Hence do-gooders may encounter "Monsters of Ingratitude."(M80) This attitude was actually influenced by Mather's alienated position in Boston at the time. He did not get the public recognition to which he felt entitled. ${ }^{36}$ Governor Dudley was an Anglican and Harvard University, of which Mather had aspired to become the president, was run by an Anglican lawyer. Hence we find in his righteous effort to organize volunteer societies for doing good an aim to by-pass the official power structure of government and the cultural establishment, a particular quality that happens to coincide with much of the anti-governmental attitudes we later find in the United States. ${ }^{37}$ As Kenneth Silverman writes: “Bonifacius enlists lesser social authorities and people of prestige-heads of households, men of wealth, minor officialdom." ${ }^{38}$ And in his preface, Mather even writes: "That a man of Good Merit, is a kind of Publick Enemy."(Mxi)

18 At the same time, Mather is genuinely motivated by a pragmatic Covenant of Works. Grace purifies the sinner and renders him "Zealous of Good Works: A Workmanship of God 
upon us, Creating us over again, by JESUS CHRIST, for Good Works."(M33-34) And later he states: "A Workless Faith is a Worthless Faith."(M37) Or: "The Motto on the Gates of the Holy City is; None but the Lovers of Good Works to enter here."(M38) Thus in paragraph 8 he writes: "What is there that I may do, for the Service of the Glorious Lord, and for the Welfare of those, for whom I ought to be concerned?"(M41) Silverman reports that this conviction even made him "overhaul the entire format of his diaries." 39 In 1711 Mather added to every entry a line headed "G.D.," i.e., "Good Devised." Thus he would keep record of his own doing good in his diary-how he helped a child to read, or gave away "Instruments of Piety" (Bibles?) and clothes to the needy.

19 As for motivation beyond America, Mather was strongly influenced by the German pietists and corresponded with August Hermann Francke in Halle. He admired their involvement in community work, in which a "reformed doctrine" entailed efforts at "reforming society" in an effort to imitate Christ. ${ }^{40}$ Thus in Bonifacius Mather addresses different civic groups paragraph by paragraph: ministers, schoolmasters, ${ }^{41}$ magistrates, physicians, military men, and lawyers: "The Reformation of the Law, and more Law for the Reformation of the World, is what is mightily called for."(M165 $)^{42}$ Thus it is clear that the Christian Reformation should spearhead a further political, social, and economic reformation. Here is his advice to rich men: "How much more Wisdom, would it be, for you to Do Good with your Estates while you Live; and at your Death do That, which may Embalm your Name to Posterity in this World, and be for your Advantage in that which you are going unto!'(M143-144). This could almost be an eulogy to the philanthropy of Andrew Carnegie. ${ }^{43}$

20 From the point of view of social organization, the crucial section of Bonifacius is paragraph 21, in which Mather makes his explicit proposal for "Reforming Societies."(M167ff.) He also calls them "Societies for the Suppression of Disorders" and acknowledges their origin in London that "began with an Heroic Resolution, \& Association, to Encounter the Torrent of Wickedness."(M167) To repeat, reform of this kind expects conformity to the Good Book: "And among other Essays to Do Good, they Scattered Thousands of Good Books, that had a Tendency to Reform the Evil Manners of the People."(M168) At the same time this prescriptive behavior is supposed to be monitored and transgressors are to be punished. Mather recites from a former account: "The Society may do Considerable things towards the Execution of Wholesome Laws, whereby Vice is to be discouraged. Offenders against those Laws may be kept under such a Vigilant Inspection, that they shall not escape a due Chastisement of their Offences."(M169 ${ }^{44}$ Hence Mather's do-gooder, the original American volunteer, subjects himself to given rules, espousing a Christian moral system of conformity. This is probably what Foner means when he talks about an "understanding of freedom as submission to a moral code." 45 Here is, finally, Mather's proposal:

That a Fit Number in a Neighbourhood, whose Hearts God has touched with a Zeal to Do Good, would Combine into a Society, to meet, when \& where they shall agree; and Consider that Case, What are the Disorders that we may see Rising among us? And what may be done, either by our selves immediately, or by others thro' our Advice, to Suppress those Disorders?(M171)

21 These "disorders" seem to be a milder, secularized version of the unstable chaos of the medieval mundus inversus. Hence they can be opposed by more practical means: Mather suggests the presence of a minister and prayer to "Bless the Design, Direct and Prosper it," two stewards "to dispatch the Businesses and Messages of the Society, and manage the Votes in it," a faithful treasurer, and a clerk, "to keep a convenient Record of Transactions 
and Purposes." These societies should act with "as Modest and Silent a Conduct as may be."(M171) Clearly, they are private organizations, and towns should have several of them.

Mather ends his proposal with ten "Points of Consideration," advising members to look for "Remarkable Disorder," scandalously behaving persons who need admonition, the attention of a minister or justices/officers who are unmindful of their duty, cases of wickedness, oppression or fraudulence, lobbying for laws, afflicted neighbors who need help, or any proposals "for our own further Advantage and Assistance, that we ourselves may be in a Probable and Regular Capacity, to Pursue the Intentions before us?"(M172-173) It is striking how closely the formulation of these points of consideration anticipates some of the rules in Benjamin Franklin's later Junto Club. ${ }^{46}$ Different from Franklin is definitely Mather's catalogue of desirables, which emphasizes, once again, his purpose of the "Propagation of the Holy and Glorious Religion of CHRIST,"(M174) an evangelism that should not "be out-done by Popish Idolators!"(M175) Mather's fear of Roman Catholic competition for the saving of souls also seems to be the motivation for his adding, as an appendix to the book, a report on the Protestant efforts to propagate religion among the Indians in New England. ${ }^{47}$ Crucial for me in his definition of "doing good" are Mather's emphasis on conformity and control, the dependence of good works on Grace, and, at the same time, a selfrighteous non-conformity towards the world and its "official" organizational forms: "None of the Wicked shall understand, but the Wise shall understand."(M180)

3. Civic Volunteerism

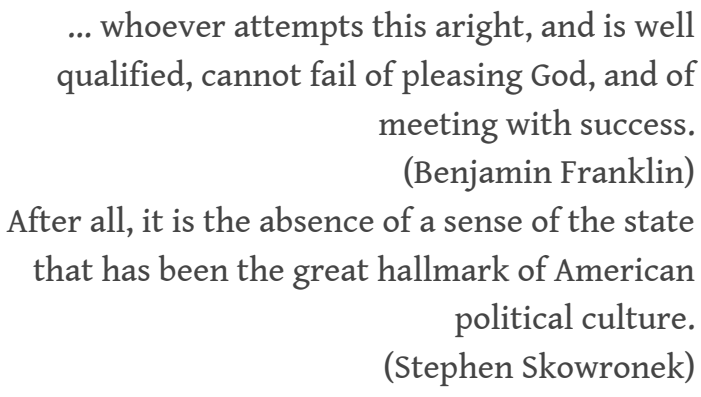

The "earliest societies formed to address social ills" and the reformation of manners were organized in England ${ }^{48}$ in the "moral revolution" following the Glorious Revolution of 1688, a phase that Cotton Mather also refers to.(M167) However, there are also origins of volunteer organization that are less religion-oriented. Belles Lettres were private reforming efforts that often had a public agenda, and in the New World they especially had an educational function. ${ }^{49}$ Formal organization of some of these efforts resulted in more official clubs, often organized as freemasonic lodges, which were based on secular and more liberal credos, and had a para-political function as debating societies outside of the power structure of the royalist state. They provided exclusive club ceremonies, codes of laws, had secretaries who kept minutes, and operated in a recognizable NGO format.

Out of this cultural environment came Benjamin Franklin, arguably the second important founding figure in the development of American volunteerism. In his Autobiography he writes: "Dr. Mather's Essays to Do Good ... perhaps gave me a turn of thinking that had an influence on some of the principle future events of my life."(F13) In 1724, after the writing of his witty Dogood papers in 1722, he paid a formal call and met the Puritan divine in person. ${ }^{50}$ Thus we may even claim a continuation and 
development of the Puritan origins of American volunteerism in Franklin's work. He is famous for his projects of improvement in colonial Philadelphia, such as his organization of the Philadelphia Public Library(F71) and the Union Fire Company,(F97) the first volunteer fire department and the origin of the myth of the American fire fighters (recently reactivated after the 9/11 disaster). Franklin also organized a volunteer militia because the Quaker government refused to raise funds for the defense of Philadelphia in the French and Indian War.(F102, 133) ${ }^{51} \mathrm{He}$ organized the private funding of a hospital(F106) and an academy building.(F109) Yet he remains best known for his private organization of street sweeping and street paving(F115) and for inventing a system of 'matching grants' to finance his projects, which involved business, private and government money and which is now a well-known fundraising procedure used by volunteer organizations. Franklin personifies private volunteering for the benefit of the public.

25 If we compare Franklin to Mather, we find the former Puritanism changed into a humanized version of Deism. A religious element is still there: "I never was without some religious principles. I never doubted, for instance, the existence of the Deity."(F74) Both similarities and differences with Mather become quite clear in the second part of Franklin's Autobiography, when he describes his "arduous project at arriving at moral perfection."(F75) His motivation manifests itself in this excerpt from his "little prayer": "Accept my kind offices to Thy other children as the only return in my power for Thy favors to me."(F80) When later, in part 3, he writes about "the essentials of every religion," Franklin suggests that "the most acceptable service to God is doing good to man."(F88) Notice how these formulations echo Cotton Mather's "good works," though stripped of Mather's religious orthodoxy. Still, we find certain common elements, such as the belief in some kind of transcendental deity and the organization of public improvement in ways that by-pass the official government. While Mather struggled against the Anglican power structure in Massachusetts, Franklin was likewise an outsider in the politics of Pennsylvania, which was dominated by the Quakers. But there is a noticeable shift of emphasis from spiritual gain to secular materialism. Franklin quotes his own observations on "My Reading of History" (already formulated in 1731) in the Autobiography: "There seems to me at present to be great occasion for raising a United Party of Virtue by forming the virtuous and good men of all nations into a regular body, to be governed by good an wise rules." And he adds that "whoever attempts this aright, and is well qualified, cannot fail of pleasing God, and of meeting with success."(F88)

The organizational form of Franklin's "Party of Virtue," beyond his own individual efforts as a "busy body," can be found in the Junto Club, an association of members who used to regularly meet on Friday evenings(F33) -the same time slot usually booked for Sabbath activities:

Our club, the Junto, was found so useful, and afforded such satisfaction to the members, that several were desirous of introducing their friends, which could not well be done without exceeding what we had settled as a convenient number, viz., twelve. We had from the beginning made it a rule to keep our institution a secret, which was pretty well observ'd; the intention was to avoid applications of improper persons for admittance, some of whom, perhaps, we might find it difficult to refuse. I was one of those who were against any addition to our number, but, instead of it, made in writing a proposal, that every member separately should endeavor to form a subordinate club, 
with the same rules respecting queries, etc., and without informing them of the connection with the Junto. The advantages proposed were, the improvement of so many more young citizens by the use of our institutions; our better acquaintance with the general sentiments of the inhabitants on any occasion, as the Junto member might propose what queries we should desire, and was to report to the Junto what pass'd in his separate club; the promotion of our particular interests in business by more extensive recommendation, and the increase of our influence in public affairs, and our power of doing good by spreading thro' the several clubs the sentiments of the Junto. (F94)

27 Note the secrecy, the twelve friends, the business, the intention of doing good. We find here an intended snowballing effect of high-minded apostles that reminds us of Cotton Mather's associations of "young men," 52 a "congregational" rather than hierarchical system ("separate club"), combined with a solid awareness of business interests. The Junto Club seems to be yet another blueprint for future volunteer networks that have come down to us in the form of Rotarians, Kiwanis, Odd Fellows, and other philanthropic business organizations.

28 Though Franklin's humanism clearly goes beyond the ideological narrowness of Mather, there is a strong element of utopian belief in his behavior, which builds on the preceding religious foundations. Thus the "secularization" of this development is ambivalent. Though distancing himself from Puritan dogma in his Deism, Franklin continues with some of the structural elements of Bonifacius and remains motivated by similarly-expressed ideals (virtue, doing good, improving young men), all of which is carried out via a secret, private, unofficial para-structure that is separate from the government.

29 Hence Franklin's approach, along with Mather, can be seen as a guiding influence on the consolidation of non-government organizational forms in the emerging United States. The neglect by the colonial English government of its American subjects caused a general distrust of government organization..$^{53}$ Rather than relying on authorities, they would create and finance their own private social infrastructure, not unlike their non-conformist ancestors who had organized their own sects outside of the Anglican Church. As John Stuart Mill observes in On Liberty (1859), liberty (a catchword of American Protestantism as well as American nationalism) tends to be defined in opposition to authority and bad government:

By liberty was meant protection against the tyranny of the political rulers. The rulers were conceived ... as in a necessary antagonistic position to the people they ruled. ... The aim, therefore, of patriots was to set limits to the power which the ruler should be suffered to exercise over the community; and this limitation was what was meant by liberty. ${ }^{54}$

30 Mill finds that this attitude results in a "still subsisting habit of looking on the government as representing an opposite interest to the public. The majority have not yet learned to feel the power of the government their power, or its opinions their opinions." 55 American volunteerism and the powerful influence of NGO's in American society can be seen as extended symptoms of precisely such attitudes. ${ }^{56}$ They are based on a long genealogy of virtuous liberty and similar notions relying on freedom, voluntary commitment and individual motivation in opposition to any kind of governing authority, although the nature of the psychological source of such free choice remains difficult to define and can be subject to manipulation. On this last point, 
consider how theorists in the humanities have deconstructed the notion of human autonomy itself. ${ }^{57}$

4. Military Volunteerism

Being compelled to volunteer is an Orwellian concept designed to put a false face on compulsion.

(Charley Reese)

31 A good test case of this issue of manipulation is when it is put into a context of coercion: when convictions have to be put into practice by force, as in the case of military volunteerism. Franklin's disdain for the British "regulars," the professionals fighting as English redcoats, is proverbial. ${ }^{58}$ And much of the military lore of the Revolutionary War is based on the declared superiority of the American militia, the minutemen, as volunteers fighting for the liberty of their own country. ${ }^{59}$ Protest against standing armies (i.e., professionals) is even inscribed into the Declaration of Independence. Thus up to the twentieth century, all American wars were fought by volunteer armies: The colonial wars, the Revolutionary War, the War of 1812, the Civil War, the Spanish-American War.

Only during World War I was the Volunteer Act of 1914 followed by a clandestine "plan to initiate a draft." As Ellis and Noyes write, "to avoid public outcry, a system was devised to make conscription look as much like volunteering as possible." ${ }^{60}$ The military was further professionalized during World War II, when many of the ancillary services, such as ambulance-driving and red cross activities, ${ }^{61}$ were delegated to volunteers: "The Federal government provided the money and often the initiative, and then found hundreds of thousands of local volunteers to take over what it had created." ${ }^{2}$ Yet the draft was seriously questioned in the Vietnam War, when it turned into a symbol of enforced participation in a highly unpopular war.

33 Since then the United States has again returned to a system of voluntary military service, although the recent shortage of recruitment for the Iraq War has raised the question of whether this will be possible in the long run. ${ }^{63}$ Indirect coercion can be found in the fact that soldiers are mainly recruited from the poor social classes, who commit out of economic necessity and because of educational incentives. Ill-trained and cash-strapped reservists tend to find themselves in a similar situation. Thus, even without the draft, the U.S. military of today consists of paid professionals. Yet as Charley Reese writes: "People have been confused because the alternative to a military draft is called an 'all-volunteer' force rather than what it is, which is a mercenary force. ... you volunteer one time to join and thereafter you are subject to compulsion." ${ }^{64} \mathrm{He}$ continues with the warning that "being compelled to volunteer is an Orwellian concept designed to put a false face on compulsion." And he comes to this stunning conclusion: "Americans need to understand the difference between patriotism and nationalism. A patriot loves his land and his people. A nationalist loves his government. The patriot voluntarily does what is necessary to protect his land and his people. A nationalist blindly obeys his government." ${ }^{\prime 65}$ We find here a wholesome combination of American voluntarism and American "patriotism" with as expected a healthy dose of antigovernment rhetoric (against so-called "nationalism"). Still, the non-American can be somewhat nonplussed by these subtle differentiations, which require further explanation. How ambivalent (not to say paradoxical) is the function of the government in the field of American volunteering? 
5. Government Volunteerism

A strong and prosperous nation must also be a compassionate nation.

(George W. Bush) guide volunteerism and use it for its own purposes. ${ }^{66}$ The relationship between government and volunteers or NGO's is a highly complex one in which both sides try to manipulate issues to their own advantage. The government does not see itself in opposition to volunteer organizations but as a partner who welcomes "private initiative." It does so mainly by selectively funding certain organizations and by eliminating support for NGO's that oppose its politics. Hence it can exert some control. ${ }^{67}$ This particular blending of government and volunteer structures has become more obvious in new umbrella organizations such as President Clinton's "AmeriCorps" 68 and President George W. Bush's "USA Freedom Corp." ${ }^{69}$ By providing central networks for volunteer recruiting, the state clearly tries to integrate volunteering as a part of its own governing and its particular governing intentions. ${ }^{70}$

35

is a recent example of this setup: The Chronicle of Philanthropy announced that the "USA Freedom Corps will be managed by a national council, whose chairman will be the president. An assistant to the president, John Bridgeland, will become executive director of the Freedom Corps and will oversee its day-to-day operations from his office in the White House." ${ }^{71}$ Bridgeland himself, in a web message titled "Why Serve?" declares that his new post will "respond to emergencies of all kinds, including the terrorist attacks of September 11, 2001." He elaborates: "Our nation is the greatest force of good in history," reminding readers of "the long tradition of service" and that "generations of Americans ... died to protect the freedom we enjoy now."72 The web site of the USA Freedom Corps features pictures of ex-presidents Bill Clinton and George Bush, Sr. visiting Tsunami victims in Thailand. It is headed by a motto from President George W. Bush: "A strong and prosperous nation must also be a compassionate nation." ${ }^{\prime 3}$ Links on this government website connect to the "We the People Book Shelf" and the "Business Strengthening America" website. ${ }^{74}$ The little ones are referred to the "USA Freedom Corps for kids."

Resistance to this new central coordination of American volunteerism can mainly be found in the Peace Corps, ${ }^{75}$ which fears losing its independence. Collin Gallagher observes on its volunteer web site that "the inclusion of the Attorney General in the USA Freedom Corps Council, of which the Director of the Peace Corps is a member, provides a mechanism whereby Peace Corps could be used for intelligence purposes by other government agencies under section 908 of the USA Patriot Act." 76 He believes that the lives of volunteers will be put at risk if they become associated with other agencies such as the CIA. Jeremy Lott talks of "a potential ticking civil-liberties time bomb known as the Terrorist Information and Prevention System, or Operation TIPS, for short." He writes that "these 'volunteers' will become the eyes and ears of the federal government-the first line of defense against an invisible terrorist threat."77 What Lott sees as a violation of American civil liberties and a "dystopian vision" of "unpaid snitches" has already greatly damaged the assumed neutrality of international aid organizations in general, the independence of which has been questioned in Iraq. Thus the United Nations headquarter was bombed, many private organizations, including Médecins Sans Frontières, ${ }^{78}$ have pulled out because they can no longer

European journal of American studies, 2-1 | 2007 
guarantee the safety of their employees, and CARE's Margaret Hassan was kidnapped and assassinated. Hence the claim that recent efforts at co-opting volunteer activities for political gains have changed the shape of aid and destroyed decades of international trust building, especially in the Near East. This example shows that the relationship between government and volunteer organizations is intricate and at the same time contested.

The current Republican administration also tries to boost the influence of corporate America. USA Freedom Corps director John Bridgeland emphasizes "a nationwide effort called "Business Strengthening America." 79 Using phrases such as "Our goal" and formulating his mission statement in the first person plural, Bridgeland invites identification with his conclusion: "If we are successful, we will also prove the premise that America's companies can do well by doing good." 80 What this economic premise means for volunteering is explored in a recent contribution by Susan J. Ellis, called "Tracking Volunteer Trends," in which she advocates the "enforced rotation of officers." In this way the know-how of running the organization spreads among more members. Ellis also recommends a "contingency plan" for terrorist attacks. Moreover, volunteer organizations should offer "short-term assignments" because "members are stressed and time-starved." Rather than emphasizing longevity, volunteer officers should "consider adding awards for rookie of the year." 81 One gets the distinct sense that in contemporary neo-liberal America citizens are somewhat exploited as gratis workers encouraged to be available for longer hours. ${ }^{82}$ The open question remains: who will lead such "time-starved" volunteers? Who will steer the direction of their American volunteerism? Who will "drive the car," as William Carlos Williams wondered in a different age? ${ }^{83}$ This is why it is so important to closely scan the concepts of American volunteer commitment and to look at the metaphors used to express it. Only after reading Cotton Mather and Benjamin Franklin can we realize that director Bridgeland, consciously or unconsciously, uses a vocabulary of American volunteerism that harks back to colonial times, when he talks of a "force for good" and doing "well by doing good." ${ }^{4}$ To be sure, these are not direct political causalities of the kind preferred by historians, but they can contribute to an ideological critique of value systems and lead to a better understanding of a particular economy of ideas.

6. Exporting Democracy: Volunteering as an International American Strategy

Ich habe über Jahre beobachten können, wie in Bosnien zahllose Vertreterinnen und Vertreter von nichtstaatlichen Organisationen, vereinzelt aber auch solche von internationalen

Organisationen oder nationalen Projekten, landauf und landab zogen, in der wohlmeinenden

Absicht, die Zivilgesellschaft zum Leben zu erwecken, während das Land zunächst noch viel verzweifelter der staatspolitischen Identität und seine Bewohner der staatsbürgerlichen Identität bedurft hätten, um die monolithische ethnische Identität überhaupt überwinden zu können. $(\text { Gret Haller })^{85}$

As the case of the "coalition of the willing" in the Iraq War shows, the foreign policy of the United States also applies the American gesture of voluntary participation to 
international cooperation, with the expectation that other countries will join in as well. Whereas in Europe the dominant image of cooperation is one of compromises and endless negotiations at European Union meetings, the image of a "coalition of the willing" implies a totally different procedure, namely one of recruiting followers for a good cause that excludes moral compromise. The goal of the activity is not negotiable, it is given rather than a new object to be constructed in a Socratic, dialogic activity. It is projected as a pre-existing essence, a good to be voluntarily selected and committed to, i.e., the emphasis is not on the making but on the act of choosing. This implies the following of a truth with an ascribed positive value. Though these conceptual distinctions may be subtle, they illustrate how the American tendency to volunteer can be projected way beyond the domains of "traditional" volunteer work. The example of the "coalition of the willing" shows that the expectations of volunteerism are prevalent at all levels of American culture. This kind of foreign policy is no aberration or coincidence but follows a logic that is identifiable in all areas of American civic life. The aim is not to negotiate what is good, but to commit to ideals. ${ }^{86}$ Volunteerism is important here because it involves a particular organizational pattern of assumed social values and possible interactions.

39 As our discussion of government involvement shows, volunteerism in the United States goes far beyond the informal. It is-much more than Europeans have formerly noticed-an integrated part of institutionalized frameworks. Let me therefore add here some very partial European perspectives based on Gret Haller's Die Grenzen der Soldarität, a treatise that extends the American sense of non-government organization into the realm of legal and constitutional issues. Haller, a former president of the Swiss national parliament, wrote her book in response to a widening gulf of values across the Atlantic that she started noticing after the terrorist attacks of $9 / 11 .{ }^{87}$ She bases her arguments on her experience as ombudsfrau for human rights in Bosnia for the OSCE (Organization for Security and Co-operation in Europe). Her central argument is about human rights, which are defined differently by U.S. Americans, who tend to individualize the responsibility for human rights violations as a matter of criminal law rather than holding the state responsible for them. ${ }^{88}$ Haller noticed that her colleagues from the United States did not think that the state should grant human rights, which were rather understood as rights that the citizen should defend against the state. Instead Americans advocated the building up of a "civil society" in Bosnia, by which they did not understand non-military organization (in the sense of Zivilgesellschaft), but non-governmental structures providing checks and balances to the power of the state.

In an effort to trace these political differences, Haller pursues a discussion on religion and secularization. Whereas religion stands above the state in the United States, in Europe, as a consequence of the Enlightenment, the state always stands above the church. ${ }^{89}$ Thus the American separation of church and state stands for an understanding of secularization that is very different from the French concept of laïcité prevalent in Europe. Haller traces this contrast to the end of the Thirty Years War in 1648, the last major religious war in Europe, after which religious conflict was to be avoided by the clear hierarchy of cuius regio, eius religio. Conversely, in America, where many of the persecuted fled, religious liberty was to be defended against the authority of the state. ${ }^{90}$ This had serious consequences for the form of government chosen by the post-colonials. 
41 In the United States the state is supposed to be less powerful, and citizens tend to be suspicious of it. Haller even calls this a "mehr oder weniger ausgeprägte Staatsfeindlichkeit."(H40) ${ }^{91}$ Still, she goes beyond Gary Wills by claiming that the United States even lacks a well-developed meaning of the state ("kein eigentlicher 'Staatsbegriff' entwickelt"). ${ }^{92}$ There is only government, and Americans do not see their nation or national identity represented by it. ${ }^{93}$ Haller therefore calls the American way a horizontal social contract ("horizontaler Gesellschaftsvertrag"), which by-passes the state as a third entity.(H48-49) ${ }^{94}$ Consequently, national identity is defined differently as well. This may precisely be Reese's point that American patriotism goes beyond nationalism.

42 Haller claims that the basic notion of the American social contract is the covenant, tracing it to the Mayflower Compact. ${ }^{95}$ Different varieties of this form of social contract can be found from "We the People" in the Constitution through the New Deal and the Great Society,(H56) and extended (in a different fashion) by the more recent Republican Contract with America. Based on this, Haller identifies as a typical feature of American national culture the urge to continually renew one's promise of belonging together(H55) $)^{96}$ in a form of "Bekenntnis," a declaration of belief. ${ }^{97}$ She insists that, whereas in Europe you belong to your nation by simple existence, in the United States you belong by declaration of belief: "Gesellschaftliche Zugehörigkeit beruht in Amerika immer auf einem Bekenntnis, während Europa die 'bekenntnisfreie Zugehörigkeit' zur Gesellschaft kennt."(H57) ${ }^{98}$ Belonging depends on an active gesture of commitment (and inversely the graceful gesture of getting admitted, as African Americans and other minorities would add here $\left.{ }^{99}\right)$. Still, Haller insists that rather than exclusion ("Ausgrenzung") of marginal groups, in the United States you have non-admittance ("Nicht-Aufnahme") into society.(H59) ${ }^{100}$ Consequently Americans constantly have to actively reconfirm their commitment to their chosen society. ${ }^{101}$

43 In the United States freedom stands for the liberty to chose and declare one's own allegiance. Like Thoreau, you aim to protect yourself from collective impositions. ${ }^{102}$ Haller thus concludes that in America freedom is freedom from the state,(H71) whereas in Europe it means freedom from the declaration of belief, possible because of the state. 103 She then relates her experience in trying to cooperate with U.S. officials and nongovernment employees in Bosnia, who were constantly advocating the building of a civil society as opposed to a strong state. ${ }^{104}$ Haller found this approach very counterproductive in a society where the old state had for many years been discredited by Communism and it was extremely difficult to build up a new state with functioning institutions.(H106) Rather than contributing to the building of a new state, Americans encouraged Bosnians to demand their rights from the state, which furthered ethnic divisions and blocked the citizens' willingness to accept the authority of a national government. Moreover, religious ties were made to look more important to Bosnians than a common state,(H128) even though they had never been very religious.(H132) The result of this was the division of Bosnia into ethnic zones in the Daytona Accords, which cemented a tripartite structure.(H120) Boundaries were set according to occupied territory, which has made the return to a multiethnic society very difficult. (H127) For Haller it is clear that the tug of power between state and NGO's, the question of who will grant human rights to the people, is the source of this development, and she sees in this the symptom of a competition between European and American values currently taking place in post-communist Eastern Europe.(H105) ${ }^{105}$ For her, the 
pervasive octagonal NYC police hats found in Bosnia(H231) are a symbol of this effort to export U.S. governmental structures abroad.

I have covered quite disparate issues in this essay in order to show that we are still far from understanding the true significance of American volunteering. There are many misunderstandings about this very basic phenomenon of American culture that still need analysis. New insights may help us re-map its function more adequately. Much more than a simple social habit of admirable efforts to "do good," the gesture of voluntary commitment underpins American social organization. Its values are inscribed in America's political and legal organization, which also implies many "noncommitments" from a European perspective of service public, as Thoreau's insights in his log cabin clearly indicate. ${ }^{106}$ Thus American volunteerism goes beyond the merely cultural "freedom of choice." It lies at the heart of American social consciousness and has been a determining factor in social, legal, and political formation in the United States since colonial times. And judging from the hotly debated contemporary concerns about volunteerism in the military and in political affairs, it will stay a relevant issue in the future.

\section{NOTES}

1. This essay is based on a presentation at the AFEA conference in Lille in 2005.

2. "In the United States, volunteering is not dissociable from democracy" (my translation), Marc Chénetier, ed., Le Volontariat aux Etats-Unis: Altruisme et Tradition, special edition of FOCUS (Paris: American Embassy, n.d. [1985]), 4.

3. Jefferson Airplane, Volunteers (RC, 1969).

4. Ted Flickinger, "Volunteerism Builds America," Illinois Parks and Recreation 29.5 (1998), http://www.lib.niu.edu/ipo/ip980905.html (13 May 2005).

5. See Eric Foner: "If asked to justify or explain their actions, public or private, Americans are likely to respond, 'It's a free country,'" The Story of American Freedom (New York, London: W.W. Norton and Company, 1998), xiii.

6. Foner, Story of American Freedom, xiii-xv.

7. William James, Essays in Radical Empiricism and a Pluralistic Universe, ed. Ralph Barton Perry, introduction by Richard J. Bernstein (New York: Dutton, 1971), 56.

8. See Hemingway's ambulance driver novel A Farewell to Arms (New York: Charles Scriber's Sons, 1929) and Faulkner's lawyer Gavin Stevens in The Town (1957), who is reported as wanting to volunteer for the American Field Service, Novels 1957-1962 (New York: Library of America, 1999), 91. 
9. Chénetier, Le Volontariat aux Etats-Unis, gives a detailed survey of volunteerism as an American vocation, providing detailed numbers and statistics, and also a section of telling quotations on "the president's point of view" with Ronald Reagan's neo-liberal angle on the significance of American volunteering. Also see the concluding chapter of Foner's The Story of American Freedom, which is on "Conservative Freedom." In it Foner exposes Lionel Trilling's naïve celebration of liberalism in America and describes how "a group of conservative thinkers began the task of reclaiming the idea of freedom" until the "Reagan Revolution would complete the transformation of freedom from the rallying cry of the left to a possession of the right," 308, 319.

10. Foner quotes the journalist Theodore White, who noticed in 1964 that civil rights demonstrators and conservative Republicans both claim the principle of freedom for themselves: "The dominant word of these two groups, which loath each other, is 'freedom,'" Foner, Story of American Freedom, 307. A correlating attitude shared by opposite sides is, according to Gary Wills, the American "fear of government": "After studying the ways our fear of government has found expression, I was struck by the persistence, through these different forms of opposition, of values that not only recurred but recurred in relatively stable proximity to each other. At times, these values uphold liberal positions, at times conservative ones. They can show up on the left or on the right; but wherever they show up, they bring along all or most of their fellows. They can be found in a hippie commune or a modern militia camp," Garry Wills, A Necessary Evil: A History of American Distrust of Government (New York: Simon and Schuster, 1999), 17.

11. This song was an anthem of the sixties protest generation, best know for its performance at the legendary Woodstock festival. For an interpretation of its revolutionary meaning, see Wayne Glausser, "Gotta Revolution, 1987: Grace Slick, Paul Kanter, and 'Volunteers of America.'" Popular Music and Society 12.2 (1988): 45-53.

12. On the voluntarism/volunteerism distinction, see Chénetier, Le Volontariat aux Etats-Unis, 1.

13. I am indebted to Chénetier's Le Volontariat aux Etats-Unis for much of this discussion.

14. Stephen Skowronek, Building a New American State: The Expansion of National Administrative Capacities, 1877-1920 (Cambridge:

Cambridge University Press, 1982).

15. Michael Schudson, The Good Citizen: A History of American Civic Life (Cambridge: Harvard University Press, 1999).

16. Wills, Necessary Evil.

17. Foner, Story of American Freedom.

18. "Where Solidarity Ends: How Europe and the United States Relate to State, Nation, and Religion" (my translation), Gret Haller, Die Grenzen der Solidarität. Europa und die USA im Umgang mit Staat, Nation und Religion (Berlin: Aufbau Verlag, 2002). All further references to this book will be included parenthetically within the text, with page number preceded by the letter $\mathrm{H}$. 
19. A well-informed example of this kind of text is Jane Dunham, "American Volunteerism: Reward and Retention," a paper presented at the NAFSA conference 2001 in Philadelphia, http://www.comsec.nafsa.org/ American\%20Volunteerism.htm (13 May 2005).

20. Bill Hybel, The Volunteer Revolution: Unleashing the Power of Everybody (Zandervan Publishing Company, 2004), cover blurb. 21. Susan J. Ellis and Katherine H. Noyes, By the People: A History of Americans as Volunteers (San Francisco and Oxford: Jossey-Bass Publishers, 1990).

22. Ellis and Noyes, By the People, 83, 86. They note that the KKK's "initiation oath required support of the United States Constitution, dedication to justice and humanity, and protection of widows and orphans," 125. Thus it saw itself as coextensive with American nationalism.

23. Ellis and Noyes, By the People, 53, 34.

24. Henry David Thoreau writes: "If private men are obliged to perform the offices of government, to protect the weak and dispense justice, then the government becomes only a hired man, or clerk, to perform menial or indifferent services. Of course that is but the shadow of a government whose existence necessitates a Vigilant Committee," Paul Lauter, gen.ed., The Heath Anthology, $4^{\text {th }}$ ed. (Boston, New York: Houghton Mifflin Company, 2002), 1732. Also Angelina Grimké writes in her Appeal to the Christian Women of The South (1836) about "Committees of Vigilance," which are footnoted by the editors of The Heath Anthology as "organized committees of vigilance to protect fugitive slaves from slave catchers," 1807.

25. I am thinking, for example, of the organization of prisons.

26. Alan Trachtenberg, The Incorporation of America: Culture \& Society in the Gilded Age (New York: Hill and Wang, 1982), 59-60.

27. This is basically Stephen Skowronek's argument when he talks about the "national administrative apparatus as the centerpiece of a new governmental order." He calls this the "Progressive state-building achievement," Building a New American State, 165, 283.

28. Cynthia Schneider, "Philanthropy and Volunteerism," http:// www.usemb.nl/013001.htm (13 May 2005).

29. Larry W. Curl, "Volunteerism American Style, from VCOS," http:// www.nvfc.org/news/hn_2003_vcos.html (13 May 2005).

30. On urgency as a motive in the American Revolution, see Robert $A$. Ferguson, "The American Enlightenment, 1750-1820," in Sacvan Bercovitch , ed., The Cambridge History of American Literature, Volume One: 1590-1820, (Cambridge: Cambridge University Press, 1994), 382-385.

31. All citizens are considered "entitled" to such equal services. In the United States, conversely, many of these infrastructural services are privately provided, and European visitors immediately notice toll roads, toll bridges, Greyhound buses, private railroads, private hospitals, charities, museums, schools, libraries, universities, concert halls, radio and TV, football teams, phone companies, the mail (parcels) ... you 
name it. Only in the wake of the recent neo-liberal revolution have Europeans gotten used to the arrival of three different parcel trucks instead of one every day, a fierce competition of constantly changing phone tariffs, and other blessings of more competitive "efficiency." Also note that in his autobiography Henry Ford claimed the notion of "service" as an important ingredient of his own philosophy of business, Henry Ford, My Life and Works (1923; reprint, Whitefish, MT: Kessinger Publishing, 2003).

32. Martin Luther, "Von der Freiheit eines Christenmenschen" (1520), http://www.fordham.edu/halsall/source/luther-freiheit.html (February 2007). 33. Foner, Story of American Freedom, 5. Alluding to John Winthrop's "Little Speech on Liberty," Foner writes, "'Christian liberty' meant submission not only to the will of God but to secular authority as well, to a well-understood set of interconnected responsibilities and duties, a submission no less complete for being voluntary," 4.

34. Cotton Mather, Bonifacius: An Essay Upon the Good that Is to Be Devised and Designed (1710), ed. David Levin (Cambridge: Harvard University Press, 1966). All further citations are taken from the Levin edition, with page number included parenthetically in the text preceded by the letter M. Original capitalization and italics are used at all times. 35. David Levin reports that already at age sixteen, as a part of his father Increase's church revival during the 1679 Synod, "Cotton Mather projected one of the first American voluntary societies for mutual aid," Cotton Mather: The Young Life of the Lord's Remembrancer, 1663-1703 (Cambridge: Harvard University Press, 1978), 74.

36. Thus, after describing the magistrate as "Vice-gerent of God," Mather argues: "Gods who Do no Good, are strange Gods. Not Gods, but another Name, too horrible to be mentioned belongs unto them."(M117) 37. Foner argues that "the separation of church and state drew a sharp line between public authority and a realm defined as 'private,' reinforcing the idea that rights exist as restraints on the power of government," Story of American Freedom, 27. Also see Wills, Necessary Evil, on this issue.

38. Kenneth Silverman, The Life and Times of Cotton Mather (New York: Harper and Row, 1984), 234.

39. Ibid., 229.

40. Ibid., 231.

41. Mather advocates a surprisingly human pedagogy in his chapter on schoolmasters, stating that "Blowes are for the Refractory Fool."(M113) 42. Note the chiasmic rhetoric, based on discursive causality.

43. Andrew Carnegie, The Gospel of Wealth (1889; reprint, Bedford, MA: Applewood Books, 1998).

44. Note the Christian use of the word "vigilant."

45. Foner, Story of American Freedom, 4. Later Foner extends this idea to the contemporary Christian Right: “... that genuine freedom meant living a moral life-voluntarily if possible, but if necessary as a result of coercion," 318. 
46. See in particular Franklin's "Rules for a Club Established for Mutual Improvement" (1728), in Benjamin Franklin, The Autobiography \& Other Writings, ed. Peter Shaw (New York: Bantam Books, 1989), 195-197. All further references to this edition will be included parenthetically within the text, page number preceded by the letter $F$.

47. Already in 1698 Mather was appointed commissioner of the New England Company dedicated to the conversion of the Indians, Silverman, Life and Times of Cotton Mather, 241.

48. John Van Horne, "Collective Benevolence and the Common Good in Franklin's Philanthropy," in J.A. Leo Lemay, ed., Reappraising Benjamin Franklin: A Bicentennial Perspective (Newark: University of Delaware Press, 1993), 429.

49. A good survey on Belles Lettres in early America is David S. Shields, "British-American Belles Letters," in Bercovitch, Cambridge History of American Literature, Volume One: 1590-1820, 307-344.

50. Levin, Cotton Mather, 74.

51. Franklin ultimately became quite ingenious at formulating resolutions that made it possible to rhetorically circumvent Quaker pacifism, e.g., when he had the Pennsylvania Assembly vote on the purchase of "bread, flower, wheat, or other grain"-other grain meaning gun powder. Or when he wanted to purchase a "fire engine": “... we will buy a great gun which is certainly a fire engine."(F106-107)

52. See Mather: "And when a Society shall in this way be increased unto a fit Number, Let it Swarm into More; who may hold an useful correspondence with one another."(M87)

53. "C'est ainsi que, dans l'Amérique coloniale, un certain nombre de tâches traditionnellement associées à la notion d'Etat dans la conscience moderne étaient du ressort de groupes privés et bénévoles: entretien des villes, service postal, éclairage urbain, sécurité des rues, etc.," Chénetier, Le Volontariat aux Etats-Unis, 6.

54. John Stuart Mill, "On Liberty" (1859), in Mary Warnock, ed., Utilitarianism and Other Writings (New York: New American Library, 1962), 126-127.

55. Ibid., 134.

56. Also see Eric Foner's telling statement: "There is no equivalent in our literature to John Stuart Mill's On Liberty," Story of American Freedom, xiv. Gary Wills even goes as far as associating anti-governmentalism with "paranoia," observing that "it makes no sense for the people to resent what they have themselves brought about," Necessary Evil, 316, 320.

57. Some of the most sophisticated work on interiority and agency can be found in the large recent output of poststructuralist analyses on American literary realism and naturalism.

58. See, for example, his ironic ballad "The King's own REGULARS; And their Triumphs over the Irregulars," (1775) in Lauter, Heath Anthology, 1033-1036. Also consider his comments in the Autobiography on the doomed campaign of the English General Braddock: "This whole 
transaction gave us Americans the first suspicion that our exalted ideas of the prowess of British regulars had not been well founded."(F131).

59. On the myth of the minutemen, also see Wills, Necessary Evil, 25-41.

60. Ellis and Noyes, By the People, 190.

61. Ellis and Noyes talk of 71,000 registered Red Cross nurses during World War II, ibid. 234.

62. Geoffrey Perrett, quoted in ibid., 232.

63. See as examples the New York Times articles by Duncan and by Kennedy: David Douglas Duncan, “Uniform Sacrifice," New York Times, 25 July 2005, http://travel2.nytimes.com/2005/07/25/opinion/25duncan.html? ex=1162270800\&en=708ece7e3747bd07\&ei=5070 (29 October 2006); David M. Kennedy, "The Best Army We Can Buy," New York Times (25 July 2005), http://travel2.nytimes.com/2005/07/25/opinion/25kennedy.html? ex=1162270800\&en=1abfaa6d7de08675\&ei=5070 (29 October 2006).

64. Charley Reese, "General Wesley Clark's Compulsory Volunteerism," King Features Syndicate (25 October 2003), http://www.commondreams.org/ scriptfiles/views03/1025-04.htm (13 May 2003). Volunteer specialist Susan J. Ellis writes about the American "all-volunteer fighting force": "It is true that in some wars (maybe even in this one [i.e., the Iraq War]) individuals enlist specifically to support the cause. But, in truth, the American military is 'voluntary,' meaning non-draft, rather than 'volunteer'. Service people receive salary and benefits ..., "' "War and Volunteers: History Repeats Itself," ENERGIZE (April 2002), http:// www.energizeinc.com/hot/2003/03apr.html (13 May 2005).

65. Reese made his statements in the context of the then presidential candidate Wesley Clark's suggestion to set up a "civilian reserve force" and observes: "Compulsory volunteerism is, of course, a contradiction in terms."

66. In her contribution on Tocqueville's observation about the great number of American newspapers, Theda Skocpol mentions the powerful influence of the Postal Act of 1792: "Voluntary associations soon learned to put out their message in 'newspaper' formats," taking advantage of the special postal rates. Skocpol calls this relationship of governmental and associational organizations "symbiotic," "What Tocqueville Missed: Government made all that 'volunteerism' possible," http://slate.msn.com/ id/2081/ (13 May 2005).

67. Skowronek points to a "national administrative apparatus as the centerpiece of a new governmental order" after 1900, "transforming ideological conflicts into matters of expertise and efficiency," and he emphasizes that "Modern American state building successfully negotiated a break with an outmoded organization of state power," Building a New American State, 165, 166, 285. However, the conservative revolution of the 1980s, while not getting rid of the "administrative apparatus," did come to power and reach back to reactivate many of the old habits of the spoils system.

68. AmeriCorps: A Program of the Corporation for National and Community Service, http://www.americorps.org/ (13 May 2005). 
69. USA Freedom Corps: Make a Difference. Volunteer, http:// www.usafreedomcorps.gov/ (13 May 2005). These initiatives have started major debates, see, for example, Richard A. Ralston, who writes for the Ayn Rand Institute, a conservative think tank, and opposes President Clinton's 1998 initiative for volunteering in schools: "Advocates who want to force students into this service have not yet explained just how 'public service' - which is used as a punishment for criminals-is morally uplifting for students," "Volunteerism Destroys Education," The Ayn Rand Institute, April 1998, http://www.aynrand.org/site/News2?

JServSessionIdr006=x9qqqsc0m3.app7a\&page=NewsArticle\&id=5404\&news_iv_ctrl=1021 (13 May 2005).

70. Chénetier on the 1980s: "Dans la vision reaganienne des choses, le bénévolat, essentiellement axé sur l'entraide et la charité, doit être organisé de façon à pouvoir décharger l'Etat des responsabilités qui lui incombent, tout spécialement depuis le New Deal ... ," Le Volontariat aux Etats-Unis, 13.

71. Ian Wilhelm and Grant Williams, "An Appeal for Action: Bush Asks Americans to Make a Major Volunteer Commitment," The Chronicle of Philanthropy, February 2002, http://www.leadershiponlinewkkf.org/emerging/ news/actionappeal.asp (13 May 2005).

72. John Bridgeland, "Why Serve?" http://www.businessweek.com/adsections/ 2003/pdf/0526volunteerism.pdf (13 May 2005).

73. USA Freedom Corps.

74. Business Strengthening America, http://www.bsanetwork.org/about/ companies.html (13 May 2005).

75. Peace Corps Online: The Independent News Forum Serving Returned Peace Corps Volunteers, http://peacecorpsonline.org/ (23 August 2005).

76. Colin Gallagher, "Peace Corps Independence, New Mandate, \& Unity of Goals," http://peacecorpsonline.org/messages/messages/2629/7449.html? 1016206221 (13 May 2005).

77. Jeremy Lott, “Volunteerism Goes Undercover: The Administration's Orwellian New Initiative," The American Prospect Online, 31 July 2002, http://www.prospect.org/webfeatures/2002/07/lott-j-07-31.html (13 May 2005). 78. See Ingrid T. Katz and Alexi A. Wright, "Collateral Damage-Médecins sans Frontières Leaves Afghanistan and Iraq," The New England Journal of Medicine 351.25 (2004): 2571-2573, http://content.nejm.org/cgi/content/ short/351/25/2571 (23 August 2005).

79. Bridgeland, "Why Serve?" See, as an Example, the Bank of America Program on Volunteerism, George Bush Library Foundation, 2001, http:// www.georgebushfoundation.org/bush/html/EndowedPrograms/

BankOfAmerica.htm (13 May 2005).

80. Bridgeland, "Why Serve?"

81. Susan J. Ellis, "Tracking Volunteer Trends," Association Management (January): 72-74, http://www.allbusiness.com/management/323846-1.html (21 February 2007).

82. See the statement by Rick Cohen of the National Committee for Responsible Philanthropy in Washington, D.C.: “Charity alone cannot and should not bear the full burden of our helping our nation's most 
disadvantaged families. Good neighbors cannot replace good government," quoted in Wilhelm and Williams, "An Appeal for Action." 83. William Carlos Williams, "To Elsie" (1923), http://rpo.library.utoronto.ca/ poem/2318.html (14 March 2007).

84. Bridgeland, "Why Serve?" "Doing well by doing good" is almost a quotation from Benjamin Franklin. See Michael Zuckerman, "Doing Good While Doing Well: Benevolence and Self-Interest in Franklin's Autobiography," in Lemain, Reappraising Benjamin Franklin, 441-451. 85. "For many years I have been able to observe how in Bosnia countless representatives of NGO's, but occasionally also some of international organizations or national projects, crisscrossed the country with the wellintended aim to bring to life the civil society, whereas the land first of all much more desperately would have needed the political identity of a state, and its inhabitants a civic identity, in order to be able to overcome the monolithic ethnic identity at all."(H194, author's translation)

86. Volunteering is also a major issue of the transcendentalist culture of reform during the American Renaissance. Consider, for example, Margaret Fuller's statement in her well-known "Dispatch 18" (1847): “I do, indeed, say that voluntary association for improvement in these particulars will be the grand means for my nation to grow and give a nobler harmony to the coming age," Lauter, Heath Anthology, 1668. This attitude can also be found in fiction-thus Brooks Thomas claims that in The Scarlet Letter Hawthorne shows “how a 'fallen woman' finds redemption by helping to generate within a repressive Puritan community the beginnings of an independent civil society. In telling that tale Hawthorne ... participates in and helps shape the contours of a powerful civic myth." And he adds: "Challenging the standard account that locates the seeds of a later democracy in the political institutions of seventeenth-century New England, the Scarlet Letter implies that the nascent formation of an independent civil society precedes and helps to generate a democratic state." "Citizen Hester: The Scarlet Letter as Civic Myth," American Literary History 13.2 (2001): 184, 203.

87. In this section in particular, the reader will notice several generalizations about "Americans" that do not do justice to the great variety of opinions and cultural beliefs within the United States. The author apologizes for these simplifications but insists that they are relevant for how non-Americans perceive America.

88. "Menschenrechtlich verantwortlich ist und bleibt immer das Staatswesen, und strafrechtich verantwortlich ist immer der einzelne Täter." (H210)

89. "Europa hat aus friedenspolitischen Gründen entschieden, dass sich die Religion dem Staat unterzuordnen habe. Die Auswanderer nach Amerika sorgten demgegenüber dafür, dass der Staat die Religion nicht beeinträchtige." $(\mathrm{H} 40)$

90. Haller finds America "von allem Anfang an von Freikirchen geprägt. ... Es fand also in der Auswanderung gleichsam eine Art sozialdarwinistische Auslese eines sektenorientierten Denkens statt."(H39) 
91. "... a more or less distinct attitude hostile to the state" (author's translation).

92. “... hasn't developed a proper concept of the state." (H40, author's translation) This seems to be a typical European observation-according to Skowronek, "Hegel refused to consider America a 'Real State' because it had not developed the national governmental forms and orientations that distinguished the state realm in Europe," Building a New American State, 6.

93. Government is seen as a kind of "rechenschaftspflichtiges Dienstleistungsunternehmen." (H47)

94. Also compare this with Wills's discussion of "lower law," Necessary Evil, 124.

95. "Gesellschaftsvertrag und biblischer Bund waren für die Puritaner dasselbe, der Bürger und der Gläubige waren identisch."(H52)

96. "In Europa ist es nicht nötig, die Existenz der staatlichen Ordnungsstruktur, welche die gesellschaftliche Integration letztlich gewährleistet, immer wieder neu festzustellen, denn sie ist etwas Drittes, das unabhänglich von der Beziehung zwischen den Individuen existiert." (H56)

97. Thus is "das Bekenntnis zu (irgend)einer Religion geradezu Voraussetzung für die Integration in as amerikanische Volk." (H41) She believes that "the professed commitment to (some) religion is virtually a prerequisite for the integration into the American people" (my translation). In the United States even non-religious people organize themselves in agnostic or even atheist social groups; see the Freedom from Religion Foundation (FFRF), http://ffrf.org/index2.php (27 February 2007); the Warrington Pagan and Agnostic Association, http:// www.freewebs.com/warringtonpagans/ (27 February 2007); the Atheist Agnostic and Non-Religious Student Association, http://studentorgs.unc.edu/ aansa/ (27 February 2007); and many others.

98. "Social belonging in America is always based on a declaration of belief, whereas Europe knows the belonging to society without declaration of belief" (author's translation).

99. See Foner on abolitionists' efforts to "extend the blessings of liberty to encompass blacks, slave and free," Story of American Freedom, xx. 100. Also consider Sacvan Bercovitch's point on "Toqueville's contrast between 'traditional' and 'modern' modes of control: 'The ruler no longer says: You must think as I do or die. He says: You are free to think differently, and to retain your life, your property, and all that you possess; but from this day on you are a stranger among us.' Its positive form can be inferred from Edwin Chapin's Massachusetts electionday sermon of 1844, The Relation of the Individual to the Republic. The self, Chapin argues, denotes 'matters of principle' and society entails 'matters of compromise,' but in the American way of 'self-government' (as nowhere else) it is "compromise not of principle but for principle,'" The Office of The Scarlet Letter (Baltimore: Johns Hopkins University Press, 1991), 30. 
101. "Wer in Amerika dazugehören will, muss erstens etwas tun und zweitens damit beweisen, dass er oder sie dazugehören will." $(\mathrm{H} 6)$ 102. See the epigraph from "Resistance to Civil Government" (1849): you only belong to a society to which you have actively committed yourself. Haller extends this in her example of the freedom to live in gated communities: “In diese geschützten Bezirke zieht sich jene Freiheit zurück, welche sicher sein will, mit keiner Zugehörigkeit und damit verbundener Verantwortlichkeit konfrontiert zu werden, für die sich der Bewohner des geschützten Bezirkes nicht aktiv entschieden hat. Diese Lebensform bindet die Freiheit an die selbstgewählte Gruppe, um sich vor kollektiver Bindung zu schützen."(H75)

103. She calls this "Zugehörigkeit auch ohne Anpassung und ohne Bekenntnis." (H72)

104. Travernise's recent New York Times article shows that American policy efforts in Iraq are similar: "But the Iraqi government has been taking note of such good works, and now, more than three years after the American invasion, the outlines of a nascent civil society are taking place," Sabrina Travernise, "Iraqi Charities Plant the Seed of a Civil Society," New York Times, 23 May 2006, http://www.nytimes.com/ 2006/05/23/world/middleeast/23civil.html? ex=1306036800en=e5a8e4137615214aei=5088partner=rssnytemc=rss ( 29 October 2006).

105. Haller is of course advocating European values, which she finds granted by a secular state rather than by religiously inspired nongovernment organizations: "Religion als öffentliche Ordnungsstruktur, welche den Zusammenhalt der Gesellschaft sicherstellt, kann dieser Kontinent nicht akzeptieren."(H137); "Religion as a public structure of order which guarantees the coherence of society is something this continent [i.e., Europe] cannot accept" (author's translation). 106. Also consider, in this context, Wills's category of "withdrawers," whom he associates with "Menckenian cynicism," Necessary Evil, 316. The other side of the coin of voluntary commitment is lack of responsibility-not voting for a particular government leaves you blameless, since you are not part of "it."

\section{AUTEUR}

\section{SÄMI LUDWIG}

Sämi Ludwig, Université de Haute-Alsace, Mulhouse, France 